of Ortho Diagnostic Systems.

Mr Justice Aldous, the High Court judge responsible for the judgement, agreed. "Chiron's patent monopoly will in the short term deter some companies from carrying out research and development," he wrote. "But that is inherent in the patent system."

Aldous said he accepted that a patent holder's rights to restrict competition and put up prices was "contrary to the public interest". But he added that this was "the price that has been accepted to secure the advantages" that the patent system offers to inventors.

Indeed, the ruling against Murex - upholding Chiron's claim on future technologies for detecting hepatitis $\mathrm{C}$ conforms with recent decisions by the EPO to grant broad patents, for example on thermostable polymerases used in the polymerase chain reaction. But such rulings, as well as similar decisions in the field of agricultural genetics (see right) are coming under increasing fire both from the scientific community and from small companies.

There is a growing sentiment in the research community that broad patent claims on basic genetic discoveries may be creating an unacceptable hurdle to researchers seeking corporate sponsorship for their research, because companies may be unwilling to support research whose potential products are owned in advance by others.

Murex and other companies contesting broad patents on the grounds that they provide an unfair monopoly are turning to 'public interest' arguments to support their case. "The patent system has perhaps gone too far [in allowing broad patents]", says Peter Silverstone, director of business development at Murex Diagnostics. "Patents should protect something that is specific."

Chiron is quick to dispute charges that broad patents discourage research, as are others in the biotechnology industry, such as Genentech, Amgen, Eli Lilly, Hoffmann La-Roche and SmithKline Beecham. This is hardly surprising, given that their commercial success increasingly depends on being the first to patent key elements of knowhow, ranging from individual gene sequences to basic gene-sequencing technology, and subsequently exploit the market position that such patents allow.

If the House of Lords does review the Appeal Court's rejection of the Biogen patent, this will come too late to influence Murex's appeal, due to be heard next year, as the Lords hearing is unlikely to take place until 1996. But it would set an important precedent for the whole European bio-technology industry.

Furthermore, the House of Lords' views on gene patenting, which is already being considered separately by a select committee, are also likely to be closely examined in US circles, given for example the current debate there (see right) over 'reasonable pricing' clauses in joint industry/federal research projects.

David Dickson

\title{
Soy-bean patent comes under fire as threat to research
}

San Francisco. An international coalition of public-interest groups and the multinational company Monsanto have filed separate challenges to a broad European patent granted to an American biotechnology company on all genetic manipulation of soy-bean plants.

Both appeals have highlighted a mixture of concerns being expressed by activist groups, government agencies, researchers and sometimes other companies in the industry about the threat that broad patents may pose to research, the dangers of a monopoly over major food crops and the potential for loss of plant diversity.

Monsanto claims that the scientific data in the soy-bean application supported a patent of far narrower scope. Jim Altemus, spokesman for the chemical company, which is based in St Louis, Missouri, says the broad coverage of the patent may discourage others from entering the soy-bean area and carrying out original research not contained in the patent. "It's just too broad in coverage," says Altemus. "We're not objecting to patents per se."

The patent, issued by the European Patent Office on 2 March, means that any company or researcher interested in genetically engineering soy beans must arrange licensing from Agracetus Inc., a subsidiary of W. R. Grace \& Co. based in Middleton, Wisconsin.

Agracetus, which uses 'gene-gun' technology to move new genes into soy beans, won the broad claim on the grounds that its scientists were the first to show that the

species could be genetically engineered by any method.

But the Rural Advancement Foundation International (RAFI), an Ottawa-based biotechnology watch-dog group that led the activist coalition's complaint, argues that the invention is neither novel nor 'nonobvious', as it is based on previous reported discoveries.

RAFI also says the patent is morally wrong because it would grant a single company a 17-year monopoly on genetic research on one of the world's most important food crops. Its challenge is intended to send a strong signal to the biotechnology industry - and to patent officials - that patenting major food crops is unacceptable, said Hope Shand, research director for RAFI-USA in North Carolina. She said the patent system was not designed for genetically engineered plants and other living things and is illequipped to handle them.

But Russell Smestad, vice president of finance and commercial development for Agracetus, argues that strong intellectual property rights have historically stimulated more active research and investment.

Agracetus has filed for a similar broadbased patent on soy-bean manipulation in the United States and Canada. It already holds a US patent for all transgenic cotton products, which is being re-examined by the US Patent Office following a challenge by the US Department of Agriculture and an anonymous party.

Sally Lehrman

\section{NIH 'should rethink pricing clause'}

Washington. The US National Institutes of Health (NIH) were urged last week by various members of their advisory councils to drop an unpopular clause that forms part of cooperative research agreements between industry and NIH intramural scientists.

The controversial clause allows the NIH to set "reasonable prices" for products developed jointly with industry. It was introduced following congressional and public anger over the cost of the antiAIDS drug AZT, which was partly developed in NIH laboratories.

Edmund Tramont, a member of the advisory council to the National Institute of Allergy and Infectious Diseases, last week told a meeting of the advisory committee to Harold Varmus, the director of NIH, that the Public Health Service is now sophisticated enough to guard against the unreasonable use of technology developed with public money. "I don't think the AZT case will arise again," he said.
Both David Guyton, an adviser to the National Eye Institute, and Timothy Wright, representing the National Institute for Dental Research, agreed. "The bottom line is that reas nable pricing clauses restrict cooperative research agreements," said Wright.

The NIH has spent much of the past year trying to decide what to do about such clauses. Many companies say they will not enter research agreements containing the clause because it discourages investment by venture capitalists.

Earlier this year, two ad hoc panels of NIH staff, extramural scientists and industrialists each agreed that something needs to be done about the clause as it now stands. But it remains unclear what the NIH, under pressure to revise the current clause but also to respect the need to protect public investment in research, will eventually recommend to the Public Health Service of the Department of Health and Human Services. H. G. 